\title{
Tunisia, Egypt, the Social Media and Political Activism
}

\author{
Pamela Ogwuazor Momah \\ Pamela-Ogwuazor Momah is a Librarian with the Nigerian Institute of International Affairs (NIIA), Lagos.
}

\begin{abstract}
The social media like facebook, twitter, flicker, blogs, MySpace, YouTube etc, has played a major part in starting and sustaining revolutions that finally led to the overthrow of régimes. This article looks at the events in north Africa, particularly Tunisia and Egypt, in the Arab awakening, with the object of ascertaining how the social media have been very critical in political activism. It concludes that in the two countries, Tunisia and Egypt, the revolutions that took place there, saw the social media establishing themselves as veritable instruments of protest and mass mobilization. Although the traditional or conventional media were also able to broadcast news, there was a big contrast between the news the traditional state media put out and the news the ordinary citizen put out on the social media networks. For the first time, the world watched first hand as the ordinary citizens brought down long standing autocratic regimes by simply utilizing the social media to call out their citizens using their 'smart phones' and new electronic gadgets they were able to bring down repressive regimes.
\end{abstract}

Key Words: social Media, Political Activism, Revolution, Arab Spring, Protest

\section{Introduction}

The social media dates back to 1978 when two computer lobbyists, Ward Christensen and Randy Soess, invented the Computer Bulletin Board System (BBS) that enabled the sharing of information amongst friends. The mosaic browser that is responsible for making the World Wide Web available to the public was developed by students from the University of Illinois. That same year, a service that allows users to create their own websites, was launched by Beverley Hills Internet. In 1994 the internet was called the information superhighway. By 1998, Friends Reunited was launched, the first social network founded in Great Britain that allows old friends to locate old school friends. By year 2000, seventy million computers had been connected to the internet. Apart from social media being a means of connecting with friends and old class mates, it is now also used for more serious tasks. The activation, mobilization and sustenance of protest politics have not been left out of this new trend. In many parts of the world the social media has played a key or important role in revolutions that bring down oppressive regimes. This new trend was amply dramatized in the 'Arab Spring', as the case studies (Tunisia and Egypt) discussed below illustrate.

\section{The Arab Awakening}

According to the 2011 "Strategic Survey, a common predicament had existed in the Arab world for a very long time. The people had had many common grievances. For a long time, there was a status quo in the Arab region that was irrevocably steeled in its old archaic rigid ways, with authoritarian regimes firmly in place. The people have for so long accepted with docility, this oppression and denial of their basic human rights by these authoritarian regimes. The people were quite aware that the way their leaders were running the affairs of state did not favor them. In some of the Arab states, the dictators were grooming their sons or close relations for dynastic succession. Rewards were given to the elites that supported the regimes, whilst those who did not were punished or had to go into exile overseas. Elections were manipulated. The structural economic reforms that were recommended by the international financial institutions, which required the removal of subsides, a ban on public sector employment, and privatization had hit the masses hard. The privatization exercise favored those that were in the good books of the regimes. The most frustrating thing for the masses was that the wealth accruing from all these austere measures was going into the pockets of the supporters of the regimes as opposed to using it to make life better for the masses. Lack of transparency, and accountability that surrounded the reforms made these economic policies very unpopular. At the same time, the prices of food, energy and other necessities of life were sky rocketing, making the masses poorer, disgruntled and unhappy. According to the Secretary-General of the Arab League, Amr Moussa, "the Arab soul is broken by poverty, unemployment and general recession". The commonest affliction in the Arab states was police brutality and the abuse of the citizenry. It is no wonder that an incident in Tunisia that would not have really caused much stir, actually led to a revolution, the 'Arab Spring' that had a domino effect throughout the Arab world, courtesy, the social media. 


\section{Tunisia}

The revolution began in Tunisia, a very unlikely place for such a thing to happen, with its secular state formation and anti-terrorism stance. President Zine el-Abidine Ben Ali and his ruling democratic party, the Rassemblement Constitutional Democratique (RCD), had ruled Tunisia for 23 years under excruciating circumstances, even though still unable to suppress the opposition. On the $17^{\text {th }}$ day of December 2010 , a 26 year old fruit seller, Bouazizi, set himself on fire after the police seized his fruit and vegetables, which he was allegedly selling on the streets without a license. This somewhat obscure event would in time set the Arab world ablaze. There was already so much dissatisfaction with the leadership of the various countries, making the Bouazizi incident the last straw that broke the caramel's back. With the rising unemployment, corruption, police brutality, inflation and now, the suicide committed by the poor Tunisian, the people felt that they had just about had enough of the hopelessness and heinous state acts. They all identified with Bouazizi's frustration. Shortly before this incident, the US government had inadvertently, through wiki leaks, exposed the extent of corruption in Ben Ali's close circle. All these factors fuelled the protests against Ben Ali's government. As the protests spread to the urban cities, the international media got interested. The citizens started posting videos unto facebook and YouTube. What was going on was being tweeted all over Tunisia and the outside world. But Ben Ali in the usual autocratic manner responded by cracking down on the media. Eventually on the $14^{\text {th }}$ day of January 2011, Ben Ali fell from power and was forced to flee the country.

The action of Bouazizi setting himself on fire in the centre of Sidi Bouzid, a small town in Tunisia, would not have reached the attention of the international news media, but for the social media. The pictures and videos of Bouazizi's body aflame and the street protests in Sidi Bouzid, were uploaded on facebook and YouTube, and the 1.6 million facebook usersall over Tunisia were able to see what was going on. Meanwhile the government had managed to block nearly all commercial video -sharing sites. A producer with $\mathrm{Al}$ - Jazeera had managed to get the pictures and video of Bouazazi's burning body and used the satellite television network to broadcast it to Tunisians, especially those who had no access to the internet. Those that saw how the crescendo of the protests was increasing and getting more and more violent, called on Ben Ali to resign. It was a combination of the conventional and social media working together to give the crisis in Tunisia an international dimension. International journalists were reached via facebook, twitter, YouTube and instant messaging, using smart phones like the blackberry. As the protests turned into a major uprising, the Tunisian government, seeing the key role the internet and social media were playing, clamped down on the free flow of communication, by disrupting it and hacking into people's e-mail and facebook accounts in order to stop them. Using an on-line tool, Google Latitude, Slim Amamou, an activist being held by the police, was able to indicate where he was being held to the outside world. Anonymous, an organized decentralized global on-line collective, was more and more involved in political activism; and they collectively attacked the Tunisian government websites and the government's home page. They were also able to provide a circumvention tool, which allowed Tunisians to get around government censorship.

Internet services and domain names were centrally controlled by the Tunisian Internet Agency (ATI), thus, making it possible for the government to block the sites that they did not want. Social network sites were not spared too. But despite this censorship, a real cyber culture had developed in Tunisia, irrespective of the prosecution of on-line journalists, bloggers and press restriction in Tunisia. But as a result of the censorship, an anti-censorship and open-source movement was established. A blog collectively founded by dissident Tunisians in exile called Newaat in 2004 exposed Ben Ali's excesses and posted pictures on YouTube and French website ('Dailymotion') to that effect. Their success made more Tunisians to use more on-line tools like "Google Earth Bombing" to tag pictures of torture and peg them on 'Google Earth' to the on-line Presidential Palace site, so that when an on-line visit is made to that site horrible pictures and videos of tortures in Tunisia would be seen by the visitor. Many activists in Tunisia that had been against censorship had already mobilized for action. The protests just gave them the appropriate avenue to unleash their arsenal. The self-immolation by Bouazizi and the resultant protests gave the activists the required platform in the social media to tell the Tunisian people and the rest of the world the true story of what was going on in that country.

\section{Egypt}

The Arabs share a common predicament. When the uprising was going on in Tunisia, the Egyptians were watching and later identified with the struggle and protests. The Egyptian activists declared January 25 a 'Day of Rage'. On Twitter, the hash tag '//jan25' was selected, so that any one searching the internet for a related information, would be able to get information about when and where the demonstration was going to take place. The details of the demonstration were also posted on facebook. Thus, there was a similarity between Tunisia and Egypt on account of the following realities:

(a) The literacy rate and internet penetration were basically the same; and

(b) Both countries have a large urban population with many young people.

In terms of press freedom, Egypt definitely had a freer press, as the government did not use large scale filtering tactics against its approximately 20 million internet users. In Egypt, many activists had used on-line tools to protest against societal ills because of the relative openness or press freedom in that country. But 
although Egypt was relatively open, the government on many occasions had also arrested and imprisoned online journalists and bloggers. This was essentially because some external attention had been brought to the internal squabbles in Egypt by on-line bloggers and other social media. A strong on-line culture with a diverse and multilingual political blogosphere, and a strong anti-torture movement, had existed in Egypt by the time the 'Day of Rage' was called. More than 20,000 Egyptians came out on that day, the $25^{\text {th }}$ day of January 2011, for the protest. They were twitting and uploading pictures and videos unto facebook and YouTube and sending instant messages through their smart phones. The Egyptian authorities, seeing how these social media outlets were fuelling the rebellion and mobilizing young people, quickly clamped down on the internet and many of the social networks. The Internet service providers were asked to cut off internet access. By the $28^{\text {th }}$ day of January 2011, Egyptians had been disconnected from the global internet.. Voice and SMS on mobile phones were shut down by government. In fact, NoorGroup was the only ISP that remained on-line. Consequently, some activists used it to continue to express their disenchantment with the regime and up-load videos and pictures unto facebook and YouTube. Although the Noorgroup was later disconnected and Egypt totally thrown into information darkness, on the $2^{\text {nd }}$ day of February, 2011, the internet was again connected in Egypt. Meanwhile, before this was done, the lack of internet connection had driven all the young people to Tahir square. Wael Ghonum, the young Google executive that created the "we are all Khaled Said" facebook page, was released and he became the public face of the young protesters. By this time, international satellite had started broadcasting live from Tahir Square, apparently or surreptitiously giving impetus to the young protesters. From Mubarak's speech on the $10^{\text {th }}$ day of February 2011, it was clear he had no intention to resign. But the protesters heightened the opposition and on the $11^{\text {th }}$ day of February 2011, it was announced that he had stepped down.

\section{Conclusion}

In conclusion, it is obvious that in the two countries, Tunisia and Egypt, the revolutions that took place there, saw the social media establishing themselves as veritable instruments of protest and mass mobilization. Although the traditional or conventional media were also able to broadcast news, there was a big contrast between the news the traditional state media put out and the news the ordinary citizen put out on the social media networks. For the first time, the world watched first hand as the ordinary citizens brought down long standing autocratic regimes. The youngsters who were at the forefront of the revolution were able to use the social media to mobilize and convince people to come out on a daily basis to take their destiny in their own hands by putting pressure on the government to rigig governance for the benefit of the citizenry. The revolution in these two counties had a domino effect in the region, as more and more countries went ahead to protest and make changes in the political leadership. The other countries in Sub-Saharan Africa also became aware of the power that the social media could wield. Africa, despite it being the least internet connected continent; social networking has become imbedded in its social and political life. A public sphere that is virtual exists. Yunasa .Z.Yau'u 2011, calls its citizens 'Netizens'. There is now growing indications that the African virtual space exerts influence on politics and governance in Africa by

(1) Providing a platform for political mobilization

(2) Allowing civil society to organize, coordinate and work together for a common cause.

(3) Allowing new social issues and problems to be articulated and be included in the policy agenda

(4) Allowing government and government functionaries to be directly reached, without any protocol

With such issues as human rights and democratization, a virtual network allows for free speech and views which can be in direct contrast of that of the government. The freedom the virtual public offers its citizens and organizations, is a source of real concern, to most African governments. The Arab spring was a trail blazer in using social media and the virtual sphere, as a tool to overthrow oppressive regimes. A medium that nobody thought could be so powerful. The rest of Africa is now more aware of the inherent power in this medium and is gradually resorting to this medium to sort out thorny issues of human right abuses and bad governance that is rampant in the continent.

\section{References}

[1] http://www.technobuffalo.com/internet/social-networking/the-history-of-the-business-of-socialmedia-infographic/

[2] Strategic Survey 2011: The Annual Review of World Affairs. (London: Rutledge, 2011)

[3] Ibid., p.46

[4] Ibid., p.59

[5] Ibid., p.99

[6] Ibid., p.99

[7] Ibid., p.99

[8] Ibid, .p.101

[9] Ibid, .p.103

[10] Yunusa. Z. Ya'u .Ambivalence and Activism: Netizens, Social Transformation and African Virtual Publics. In: Africa Development. XXXVII (1), 2012, 86.-102.

[11] Yunusa. Z. Ya'u .p.95 